\title{
Neutrophil function in patients with primary Sjögren's syndrome: relation to infection propensity
}

Section of Rheumatology, Department of Medicine, University Hospital, Akademiska Sjukhuset, S-751 85 Uppsala, Sweden

B Gudbjörnsson

N Feltelius

R Hällgren

Laboratory for

Inflammation Research, Department of Clinical Chemistry,

University Hospital, Akademiska Sjukhuset, Uppsala, Sweden $P$ Venge

Correspondence to: Dr Gudbjörnsson.

Accepted for publication 28 August 1990

\author{
Björn Gudbjörnsson, Nils Feltelius, Roger Hällgren, Per Venge
}

\begin{abstract}
The function of neutrophils was studied in 23 consecutive patients with primary Sjögren's syndrome and in 35 healthy controls. Nineteen patients $(83 \%)$ had extraglandular symptoms and nine patients $(39 \%)$ had recurrent bacterial infections. The patients had a marked reduction of neutrophil adherence, especially those with recurrent bacterial infections, and reduced opsonic activity of plasma. Increased random migration of isolated neutrophils was found in the patients with a propensity for bacterial infections. Chemotaxis and chemokinesis, phagocytosis, chemiluminescence production, and the intracellular neutrophil contents of lactoferrin and lysozyme were normal. The various aspects of neutrophil function tested in this study were not related to disease duration or to inflammatory disease activity. The impaired neutrophil adherence may play a part in the increased propensity for bacterial infections seen in patients with primary Sjögren's syndrome.
\end{abstract}

Sjögren's syndrome is a chronic inflammatory autoimmune disorder characterised by lymphocytic cell infiltration of exocrine glands. Similar infiltrates may invade visceral organs and cause several extraglandular manifestations, including lung symptoms. ${ }^{1-3}$ Invasion of the lower respiratory tract by lymphocytes and plasma cells in the mucous glands of the small airways gives rise to focal atelectasis and bronchiectasis with recurrent infections. ${ }^{2}{ }^{3}$ Many authors report that infections, both pneumonia and upper respiratory tract infections as well as oral candidiasis and bacterial conjunctivitis, are a major cause of morbidity in patients with Siögren's syndrome. ${ }^{3-5}$ Shearn reported that $66 \%$ of patients with this disease had pneumonia at necropsy and as the principal cause of death. ${ }^{6}$ The propensity for pulmonary infections may partly be dependent on tracheobronchial dryness. The mucociliary clearance rate of inhaled polystyrene particles labelled with technetium$99 \mathrm{~m}$ is reported to be unaffected in patients with Sjögren's syndrome. ${ }^{7}$ Other mechanisms of importance for a normal host defence include the number and function of granulocytes. ${ }^{8}$ Leucopenia of unknown cause has been noted in patients with Sjögren's syndrome. ${ }^{29}$ The neutrophil function has been little studied in this disorder, but the increased propensity for bacterial infections in rheumatoid arthritis and systemic lupus erythematosus has partly been attributed to abnormal neutrophil functions. ${ }^{10-12}$

This study aimed at elucidating the possible role of neutrophils in the disease process and the increased risk for bacterial infections in Siögren's syndrome. Various functional aspects of neutrophils were studied: migration, phagocytosis, chemiluminescence production, adherence, chemotactic and chemokinetic properties, and cellular contents of lactoferrin and lysozyme. Patients with Sjögren's syndrome without any evidence of additional autoimmune connective tissue disease were studied to avoid the influence of any concomitant disease on neutrophil function.

\section{Patients and methods}

PATIENTS AND CONTROLS

Twenty three consecutive patients ( 21 women, two men), mean age 53 years (range 23-72), with primary Sjögren's syndrome according to the Copenhagen criteria ${ }^{13}$ were studied. The onset of disease had occurred two to 21 years (mean nine years) before the study.

Four patients $(17 \%)$ had only glandular symptoms (oral and ocular symptoms), whereas 19 patients $(83 \%)$ had extraglandular manifestations: Raynaud's phenomenon, non-erosive arthritis, kidney stones, neuropathy, or leucopenia. Nine patients $(39 \%)$, had an increased propensity for recurrent infections-that is, three or more bacterial infections: bacterial pneumonia (six patients), sinusitis (two), and recurrent upper airway infections and cytomegalovirus pneumonia (one). Only three patients were receiving low doses of corticosteroids (prednisolone $5-7.5 \mathrm{mg} /$ day) at the time of blood sampling. Two of these patients were also treated with chloroquine and azathioprine respectively. Five patients had received nonsteroidal anti-inflammatory drugs at some time, but these drugs were not being taken at the time of this study. None of the other patients was receiving drugs. No patient had overt infectious symptoms at the time of evaluation. Thirty five healthy laboratory staff, who were taking no drugs, served as controls. Their mean age was 33 years, range $24-43$.

\section{BLOOD SAMPLING AND POLYMORPHONUCLEAR} CELL PREPARATION

Leucocyte and differential counts, haemoglobin concentration, erythrocyte sedimentation rate, haptoglobin, and $\mathrm{C}$ reactive protein were measured at the department of clinical chemistry, University Hospital, Uppsala.

MEASUREMENTS OF NEUTROPHIL FUNCTION Neutrophils were isolated from venous blood treated with heparin (Venoject, Terumo, Japan) as previously described. ${ }^{14} 15$ 
Neutrophil adherence was assayed by passing $1 \mathrm{ml}$ of the heparinised whole blood through 75 mg of scrubbed nylon fibre (Fenwal lab, Deerfield, United States) packed into $1 \mathrm{~cm}$ of an Eppendorf-tips (Treff, Degersheim, Switzerland). The difference between the number of neutrophils measured by Technicon $\mathrm{H} 1$ in the original blood sample (A) and those recovered in the effluent (B) was taken to indicate the number of cells adhering $((1 \% 0$ $\mathrm{B} / \mathrm{A}) \times 100 \%)$. Tests were performed 60 minutes after blood sampling and in duplicate.

Neutrophil migration was assayed by a modified Boyden chamber. ${ }^{15}$ Random migration of isolated patient neutrophils was measured with Gey's solution below the filter, ${ }^{16}$ and chemotaxis was determined with $10 \%$ complement activated, heated $\left(56^{\circ} \mathrm{C}, 30\right.$ minutes) serum or $N$ formyl-methionyl-leucyl-phenylalanine (Sigma, St Louis, United States) below the filter. The chemotactic activity of patient serum was measured as the migration of normal neutrophils towards $10 \%(\mathrm{v} / \mathrm{v})$ fresh patient serum below the filter. The chemokinetic activity in patient serum was measured as the migration of normal -neutrophils suspended in either $20 \%$ fresh or $10 \%$ heat inactivated $\left(56^{\circ} \mathrm{C}, 30\right.$ minutes) serum towards Gey's solution below the filter. The analyses were performed as described in detail previously. ${ }^{17-19}$ The presence of chemokinetic inhibitory factors in serum was measured. ${ }^{20}$

Neutrophil phagocytosis was measured by kinetic particle uptake, in which the particles were either coated with human IgG (AB Kabi, Stockholm, Sweden) or coated with IgG and C3b obtained by the incubation of IgG particles in $20 \%$ (v/v) fresh serum (IgG-C3b particles). ${ }^{15} 21$

Opsonic activity of plasma was measured in heparinised whole blood. To the blood suspension $100 \mu \mathrm{l}$ of luminol $(1 \mathrm{~g} / \mathrm{l})$ was added and the mixture was preincubated as above. Nonopsonised zymosan particles $(100 \mu \mathrm{l} ; 4 \mathrm{mg} / \mathrm{ml}$ ) were added and the reaction recorded. The time taken for the chemiluminescence response to leave the baseline value was used as an expression of the opsonic activity of the blood.

The rate of production of light emission as a consequence of the respiratory burst was evaluated by chemiluminescence measurements in whole blood and isolated neutrophils. Analyses were performed in a Biocounter M2010 (Lumac $B V$, The Netherlands) thermostatically controlled at $37^{\circ} \mathrm{C} .^{22}$ Briefly, $50 \mu \mathrm{l}$ of the whole blood was added to a plastic tube placed in the Biocounter. After five minutes either luminol (1 $\mathrm{g} / \mathrm{l})$ or lucigenin $(0.5 \mathrm{~g} / \mathrm{l})$ was added and incubated for an additional five minutes and then placed in the Biocounter. Thereafter, 100 $\mu l$ of serum opsonised zymosan was added; the chemiluminescence response was recorded graphically and expressed as relative light units per $10^{6}$ neutrophils and calculated from the peak of the curve. Chemiluminescence production of purified neutrophils was measured in the Biocounter M2010 after mixing $100 \mu l$ of the cell suspension $\left(1 \times 10^{6}\right.$ cells $\left./ \mathrm{ml}\right), 100 \mu \mathrm{l}$ of serum opsonised zymosan, and either $100 \mu \mathrm{l}$ of luminol $(0.025 \mathrm{~g} / \mathrm{l})$ or lucigenin $(0.1 \mathrm{~g} / 1)$. The results were expressed as relative light units $/ 10^{6}$ cells from the peak of the curve.
The intracellular concentrations of lactoferrin and lysozyme were measured by radial immunodiffusion after extraction of the cells by $N$-cetyl$N, N, N$-trimethylammonium bromide (Merck, Dramstadt, W Germany). ${ }^{23}$

\section{STATISTICS}

Student's $t$ test was used for the statistical evaluation of arithmetical data. Linear correlation analysis of data was used as indicated.

\section{Results}

The number of blood neutrophils was similar in patients with primary Sjögren's syndrome and in healthy controls. No difference was seen between patients subgrouped with respect to infection propensity.

The inflammatory activity was defined by erythrocyte sedimentation rate and acute phase proteins. The median values for the patients were erythrocyte sedimentation rate $20 \mathrm{~mm} / \mathrm{h}$, range 2-105 (normal $2-15 \mathrm{~mm} / \mathrm{h}$ ), haptoglobin $2 \cdot 1 \mathrm{~g} / 1$, range $1 \cdot 1-3 \cdot 9$ (normal $0 \cdot 2-1 \cdot 4 \mathrm{~g} / \mathrm{l}$ ), and $C$ reactive protein $<10 \mathrm{mg} / \mathrm{l}$, range $<10-22$ (normal $<10 \mathrm{mg} / \mathrm{l}$ ). Thus most patients had low or moderate inflammatory activity.

\section{ADHERENCE OF NEUTROPHILS}

The adherence of neutrophils was slightly, but significantly less $(p<0.05)$ in the whole patient group than in the controls. This defect was seen particularly in the subgroup of patients with recurrent infections $(p<0.01$, fig 1$)$.

\section{NEUTROPHIL CHEMOTAXIS}

There was no significant difference between the whole patient group and the controls in random migration of neutrophils. Greater random migration was seen in the subgroup of patients with recurrent bacterial infections $(p<0.01)$

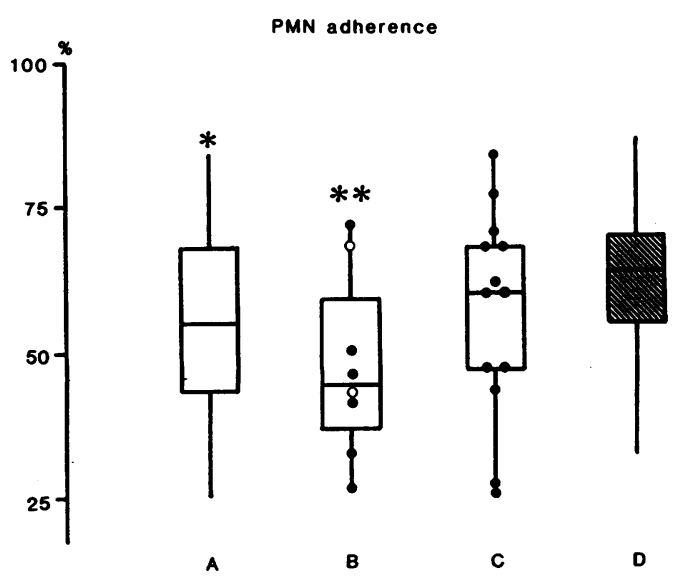

Figure 1 Adherence of neutrophils from $(A)$ patients with primary Sjögren's syndrome $(n=21)$. The patients were subgrouped according to propensity for bacterial infections: $(B)$ Recurrent infections $(n=8)$ and $(C)$ no recurrent infections $(n=13)$. The data are presented as box plots with medians, first and third quartiles, and actual ranges. The individual patient values are indicated by filled circles. The open circles indicate two patients treated with corticosteroids. The control group $(n=29)$ is illustrated by the shaded box (D). Patient groups were compared with controls: ${ }^{*} p<0 \cdot 05$;
${ }^{*}<0.01$. 
Random migration

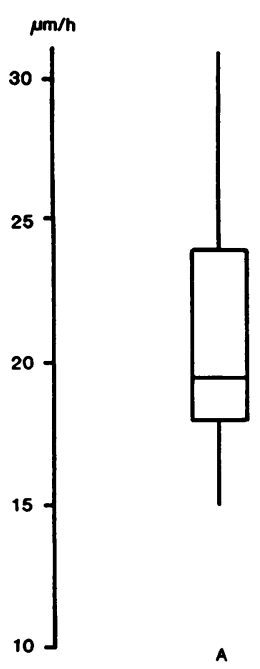

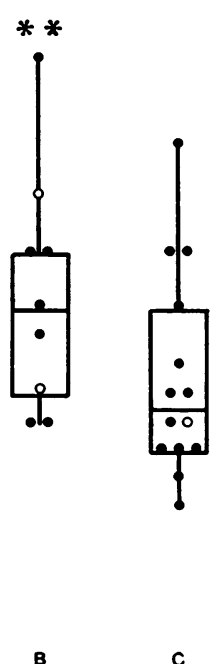

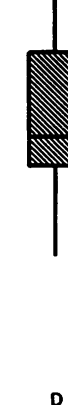

Figure 2 Random migration of neutrophils isolated from (A) patients with primary Sjögren's syndrome $(n=23)$. The patients were subgrouped according to propensity for bacterial infections: $(B)$ Recurrent infections $(n=9)$ and $(C)$ no recurrent infections $(n=14)$. The data are presented as box plots with medians, first and third quartiles, and actual ranges. The individual patient values are indicated by filled circles. The open circles indicate three patients treated with corticosteroids. The control group $(n=35)$ is illustrated by the shaded box (D). Patient groups were compared with controls: $* * p<0.01$.

than in the controls (fig 2). Other analyses reflecting the chemotactic or chemokinetic activities of neutrophils (table 1) or the chemotactic and chemokinetic activities of serum (data not shown) were similar in patients, subgroups of patients, and controls. One of the patients had a heat labile chemokinetic inhibitory factor in her serum.

\section{NEUTROPHIL PHAGOCYTOSIS}

The phagocytic uptake rate of IgG and IgG-C3b coated particles of isolated neutrophils from patients with primary Sjögren's syndrome, with or without a history of infections, did not differ from the rates for controls (table 2).

\section{OPSONIC ACTIVITY OF PLASMA}

Opsonic activity of plasma was significantly prolonged in patients with primary Sjögren's syndrome compared with the control group $(p<0.05)$. This difference was only present in patients without recurrent bacterial infections $(p<0.01)$, and there was also a significant difference between the patients subgrouped with respect to infection propensity $(p<0.01$; fig 3).
Opsonic activity of plasma
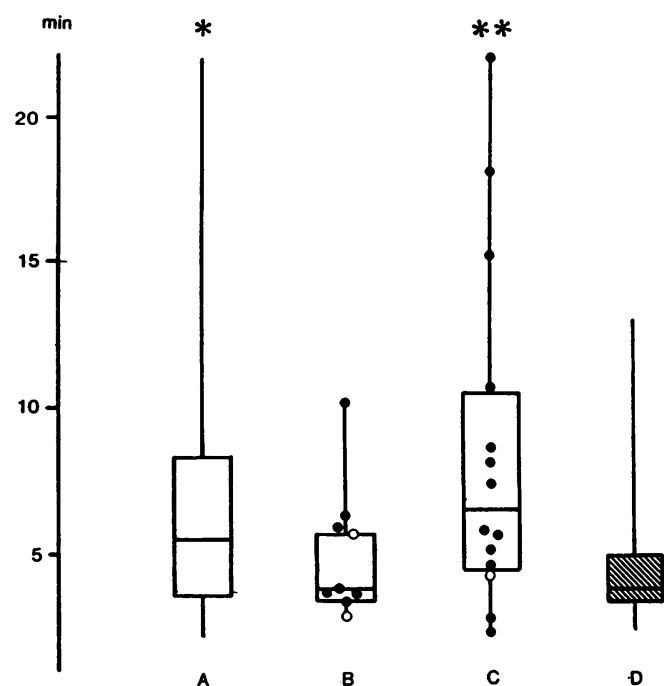

Figure 3 Opsonic activity of plasma from $(A)$ patients with primary Sjögren's syndrome $(n=23)$. The patients were subgrouped according to propensity for bacterial infections: $(B)$ Recurrent infections $(n=9)$ and $(C)$ no recurrent infections $(n=14)$. The data are presented as box plots with medians, first and third quartiles, and actual ranges. The individual patient values are indicated by filled circles. The open circles indicate three patients treated with corticosteroids. The control group $(n=35)$ is illustrated by the shaded box (D). Patient groups were compared with controls: ${ }^{*} p<0.05$; ${ }^{* *} p<0 \cdot 01$.

WHOLE BLOOD CHEMILUMINESCENCE

Neither luminol nor lucigenin enhanced chemiluminescence of whole blood was altered in patients with primary Sjögren's syndrome compared with controls. There was a minor, but significant difference $(p<0.05)$, however, between the subgroups of patients, with lower luminol enhanced chemiluminescence activities in patients with recurrent infections.

\section{CHEMILUMINESCENCE OF PURIFIED PERIPHERAL BLOOD NEUTROPHILS}

The luminol enhanced chemiluminescence of purified neutrophils induced by zymosan or phorbol myristate acetate was normal in patients with primary Sjögren's syndrome. Chemiluminescence enhanced by lucigenin and induced by serum opsonised zysoman, however, was reduced in patients without a history of infections both compared with the controls $(p<0.05)$ and with patients with recurrent infections $(\mathrm{p}<0.01 ;$ table 3$)$.

INTRACELLULAR LACTOFERRIN AND LYSOZYME The neutrophil contents of lactoferrin or

Table 1 Random migration and chemotaxis of polymorphonuclear neutrophils $(\mu m / h)$ from patients with primary Sjögren's syndrome and subgrouped with respect to infection propensity: $(A)$ patients with and $(B)$ without history of recurrent bacterial infections. Data are given as median (range)

\begin{tabular}{|c|c|c|c|c|}
\hline & $\begin{array}{l}\text { Patients } \\
(n=23)\end{array}$ & $\begin{array}{l}(A) \\
(n=9)\end{array}$ & $\begin{array}{l}(B) \\
(n=14)\end{array}$ & $\begin{array}{l}\text { Controls } \\
(n=35)\end{array}$ \\
\hline $\begin{array}{l}\text { Random migration } \\
\text { Chemotaxis }\end{array}$ & $19(15-31)$ & $21 \cdot 5(17-31)^{* *}$ & $18 \cdot 5(15-28)$ & $19(15-24)$ \\
\hline $\begin{array}{l}\text { In presence of fMLPY } \\
\text { In activated serum } \\
\text { Chemokinetic activity in presence of normal serum }\end{array}$ & $\begin{array}{l}33(3-99) \\
69(45-104) \\
93(68-127)\end{array}$ & $\begin{array}{rc}33 & (5-57) \\
76 & (45-104) \\
107 & (68-127)\end{array}$ & $\begin{array}{l}35 \quad(3-99) \\
65 \quad(54-101) \\
87 \cdot 5(69-116)\end{array}$ & $\begin{array}{l}29(5-78) \\
76(47-121) \\
90(57-131)\end{array}$ \\
\hline
\end{tabular}

**Statistical differences between patients and controls were tested; $p<0.01$

ffMLP $=N$-formyl-methionyl-leucyl-phenylalanine. 
Table 2 Phagocytic uptake rates of IgG and IgG-C3b coated particles of isolated neutrophils from patients with primary Sjögren's syndrome and subgrouped with respect to propensity for bacterial infection: $(A)$ patients with and $(B)$ without history of recurrent bacterial infections

\begin{tabular}{|c|c|c|c|c|}
\hline & \multicolumn{2}{|c|}{$\begin{array}{l}\text { Phagocytosis of } \operatorname{Ig} G \\
\text { particles }\left(\min ^{-1}\right)\end{array}$} & \multicolumn{2}{|c|}{$\begin{array}{l}\text { Phagocytosis of } I g G-C 3 b \\
\text { particles }\left(\min ^{-1}\right)\end{array}$} \\
\hline & Median & Range & Median & Range \\
\hline $\begin{array}{l}\text { Control group }(n=30) \\
\text { Primary Siögren's syndrome }(n=23) \\
\text { Subgroup A }(n=9) \\
\text { Subgroup B }(n=14)\end{array}$ & $\begin{array}{l}0.34 \\
0.33 \\
0.42 \\
0.25\end{array}$ & $\begin{array}{l}0 \cdot 11-0 \cdot 80 \\
0 \cdot 13-0 \cdot 58 \\
0 \cdot 18-0 \cdot 80 \\
0 \cdot 11-0 \cdot 51\end{array}$ & $\begin{array}{l}0 \cdot 75 \\
0.69 \\
0.67 \\
0.69\end{array}$ & $\begin{array}{l}0 \cdot 28-1 \cdot 47 \\
0 \cdot 27-1 \cdot 31 \\
0 \cdot 49-1 \cdot 31 \\
0 \cdot 27-1 \cdot 09\end{array}$ \\
\hline
\end{tabular}

lysozyme were similar in patients, in patient subgroups, and in controls (table 4).

\section{RELATION TO INFLAMMATORY ACTIVITY OR} DISEASE DURATION

None of the neutrophil functions studied was related to the serological inflammatory activity, the presence or absence of extraglandular features, or to the disease duration. No influence on results due to drugs being taken was found.

\section{Discussion}

The evaluation of neutrophil function in patients with Sjögren's syndrome showed that the essential activities of this cell, such as phagocytosis, chemotaxis, and chemokinesis, were normal. Other neutrophil activities, such as adherence, were impaired, however, as well as the opsonic activity of plasma. These abnormalities were not related to the disease duration or the inflammatory activity defined by acute phase plasma proteins, but were partly linked to increased propensity for bacterial infections. It is well known that infections may influence neutrophil function, ${ }^{24}{ }^{25}$ but none of our patients had overt symptoms of infection at the time of investigation. Some irregular abnormalities were seen in the oxidative metabolism of the neutrophils, though most of the analyses were normal

The phagocytic ability of isolated neutrophils was studied in a buffer medium, and the uptake rates of IgG and of complement opsonised IgG particles were calculated. The phagocytic uptake in this system is dependent on the Fc and $\mathrm{C} 3 \mathrm{~b}$ receptors of the cell, the major receptors promoting recognition, adherence, and, finally, internalisation of particles. ${ }^{26}$ Neutrophil phagocytosis measured by the uptake of latex particles has previously been reported to be normal in
Table 4 Lactoferrin and lysozyme concentrations in neutrophils from patients with primary Sjögren's syndrome. The patients were subgrouped with respect to propensity for bacterial infection: (A) patients with and $(B)$ without history of recurrent infections. Data are given as median (range)

\begin{tabular}{lrrr}
\hline & $n$ & Lactoferrin & \multicolumn{1}{c}{ Lysozyme } \\
\hline Controls & 16 & $101(60-177)$ & $82(40-169)$ \\
Primary Sjögren's syndrome & 23 & $105(37-167)$ & $100(46-180)$ \\
Subgroup A & 9 & $95(52-132)$ & $103(46-114)$ \\
Subgroup B & 14 & $103(37-167)$ & $103(46-180)$
\end{tabular}

patients with Sjögren's syndrome, ${ }^{27}$ but Schopf et al suggested a selective functional Fc receptor defect in a single patient with primary Sjögren's syndrome. ${ }^{28} \mathrm{An}$ increased incidence of Fc receptor mediated phagocytosis has previously been seen in neutrophils from patients with rheumatoid arthritis ${ }^{21}$ and subjects prone to infection. ${ }^{29}$ In our consecutive series of unselected patients with primary Sjögren's syndrome we found that almost $40 \%(9 / 23)$ of them had recurrent bacterial infections, but they showed normal neutrophil phagocytosis.

The initial step in the phagocytic process is the random migration of neutrophils - that is, the chemokinetic movement, to the site of infection or inflammation. Impaired random migration has been shown in previous studies on patients with an enhanced susceptibility to bacterial infections. ${ }^{30} 31$ Isolated neutrophils from most patients with Sjögren's syndrome had normal random migration, whereas those from patients prone to infection showed stimulated chemokinesis. The relevance of this latter finding is uncertain, but it is consistently found in other inflammatory diseases ${ }^{32}$ and may constitute part of the physiological response to infection. At the time of our investigation, however, none of our patients was clinically infected. In recent studies on patients with acute bacterial infections we have found a sustained rise in the chemokinetic response of neutrophils lasting several weeks after recovery from the acute infection (Pauksen $K$, Venge $P$, unpublished data). The patients had a normal chemotactic movement of isolated neutrophils, as tested in a Boyden chamber with $N$-formylmethionyl-leucyl-phenylananine and complement activated serum as chemoattractants. The chemotactic and chemokinetic activities in serum samples of our patients were also normal. These findings are in contrast with the results of Pennec and co-workers, ${ }^{27}$ who reported

Table 3 Luminol and lucigenin enhanced chemiluminescence in whole blood and by isolated neutrophils from patients with primary Sjögren's syndrome. The chemiluminescence of neutrophils was induced by serum opsonised zymosan and with phorbol myristate acetate. The patients were subgrouped with respect to propensity for bacterial infection: $(A)$ patients with and $(B)$ without history of recurrent infections. Data are given as median (range)

\begin{tabular}{|c|c|c|c|c|}
\hline $\begin{array}{l}\text { Chemiluminescencet } \\
\text { (CL) }\end{array}$ & $\begin{array}{l}\text { Patients } \\
(n=23)\end{array}$ & $\begin{array}{l}A \\
(n=9)\end{array}$ & $\begin{array}{l}B \\
(n=14)\end{array}$ & $\begin{array}{l}\text { Controls } \\
(n=35)\end{array}$ \\
\hline $\begin{array}{l}\text { In whole blood: } \\
\text { CL-luminol } \\
\text { CL-lucigenin }\end{array}$ & $\begin{array}{l}270(100-170) \\
535(160-1300)\end{array}$ & $\begin{array}{l}255(100-372)^{*} \\
520(210-835)\end{array}$ & $\begin{array}{l}352 \cdot 5(120-740)^{*} \\
530(160-1300)\end{array}$ & $\begin{array}{l}310 \quad(60-1100) \\
562.5(180-970)\end{array}$ \\
\hline $\begin{array}{l}\text { Of isolated neutrophilsł } \\
\text { (a) CL-luminol } \\
\text { CL-lucigenin } \\
\text { (b) CL-luminol } \\
\text { CL-lucigenin }\end{array}$ & $\begin{array}{rl}22 & 540(1440-32 \\
8 & 340) \\
200(5000-16 & 100) \\
2070(2460-32640) \\
2 & 200(300-6200)\end{array}$ & $\begin{array}{c}20360(3360-31140) \\
11200(6900-16100)^{* *} \\
19200(9040-32540) \\
2020(300-6080)\end{array}$ & $\begin{array}{rl}22 & 620(1440-32340) \\
8000(5000-11 & 100)^{* * *} \\
21320(2460-32440) \\
2350(690-6200)\end{array}$ & $\begin{array}{rl}25 & 240(7760-32540) \\
9800(4200-18 & 800)^{*} \\
23 & 100(5200-32700) \\
2 & 400(600-11640)\end{array}$ \\
\hline
\end{tabular}

Statistical differences between patients and controls were tested: ${ }^{*} \mathrm{p}<0.05 ;{ }^{* *} \mathrm{p}<0.01$

tChemiluminescence was expressed as relative light units per $10^{6}$ neutrophils.

fChemiluminescence of isolated neutrophils induced by (a) serum opsonised zymosan and (b) phorbol myristate acetate. 
markedly reduced neutrophil chemotaxis and chemokinesis in patients with primary Sjögren's syndrome, partly due to primary cell abnormality and partly also to a serum inhibitory effect. The reason for the discrepancy between these results and ours is not known. Differing drug regimens and inflammatory activity might have had an influence. Most of our patients were not taking drugs and had a modest inflammatory activity, when judged by the actue phase reaction. Unfortunately, Pennec et al gave no information about the inflammatory activity or whether their patients were treated with chloroquine or other antirheumatic drugs. These points may be essential to the interpretation of the results obtained. One of the patients with primary Sjögren's syndrome, however, had heat labile chemokinetic inhibitory activity in serum. Such a serum inhibitor has previously been reported in patients with chronic lymphocytic leukaemia. ${ }^{20}$

Plasma from our patients had impaired opsonic ability. Opsonisation is partly dependent on complement factors, and during bacterial infections plasma opsonic ability is enhanced. ${ }^{33}$ The plasma opsonic activity is inhibited by certain plasma components-for example, rheumatoid factors. ${ }^{34}$ The impaired opsonic ability found in our patients may be due to such antiopsonic plasma activity. We found no relation between the opsonic activity and the presence of rheumatoid factors, however.

After internalisation of micro-organisms in the neutrophil phagosome they are killed by products released from granules or produced by oxidative metabolism. ${ }^{34}$ The oxygen dependent system consists of myeloperoxidase, hydrogen peroxide, oxygen, and superoxide anions. ${ }^{34}$ The oxygen independent system consists of certain granule proteins, such as lactoferrin and lysozyme. $^{34}$ Abnormalities in these systems may be linked to an increased propensity for bacterial infections. ${ }^{36}$ Neutrophils from our patients contained normal contents of the granule proteins lactoferrin and lysozyme.

During neutrophil activation the cells emit light. The chemiluminescence of the cell is associated with the respiratory burst and can be correlated in time with an increased formation of superoxide anions and hydrogen peroxide. $^{36}$ Although we noted slight abnormalities in chemiluminescence activities, the overall impression is that the oxidative metabolism of neutrophils is unaffected in patients with primary Sjögren's syndrome, which agrees with the findings of Pennec et al. ${ }^{27}$

Neutrophils from patients with primary Sjögren's syndrome were less adherent to nylon fibre columns than those from controls. This activity is believed to reflect the in vivo adhesion of neutrophils to vascular endothelium. Reduced adherence function of neutrophils is associated with increased risk for bacterial infections. ${ }^{38}$ When we analysed our patients we found that only those who were prone to infection had impaired neutrophil adherence. This is in contrast with the normal adherence reported by Pennec et al in patients with Sjögren's syndrome. ${ }^{27}$ Again the difference in results may be attributed to drug regimens as it has been reported that anti-inflammatory drugs may enhance the adherence functions of neutrophils. $^{38} 39$

In conclusion, this study has shown that most neutrophil functions are normal in patients with primary Sjögren's syndrome. The impaired neutrophil adherence found may partly underlie the increased propensity for bacterial infections seen in this disease.

The skilful technical assistance of Mrs Ulla Carin Johansson and Mrs Eva Brunell is greatly appreciated. This study was supported by grants from the Sätra Brunns fund and the Swedish Medical Research Council.

1 Moutsopoulos H M, Chused T M, Mann D L, et al. Sjögren's syndrome (sicca syndrome): current issues. Ann Intern Med 1980; 92: 2112-226.

2 Block K J, Buchanan W W, Wohl M G, Bunim J J. Siögren's syndrome: a clinical pathological and serological study of 62 cases. Medicine (Baltimore) 1965; 44: 187-231

3 Hunninghake G. Fauci A. Pulmonary involvement in the collagen vascular diseases. Am Rev Respir Dis 1979; 119. collagen

4 Strimlan C V, Rosenow E C III, Divertie M B, Harrison E G. Pulmonary manifestations of Sjögren's syndrome. Chest 1976; 70: 354-61

5 Rankow R, Polayes I. Inflammatory conditions of the salivary glands in diseases of the salivary gland. Philadelphia: Saunders, 1976: 211-30.

6 Shearn M A. Sjögren's syndrome. Major Problems in Internal Medicine 1971; 2: 135-43.

7 Fairfax A J, Haslam P L, Pavia D, et al. Pulmonary disorders associated with Siögren's syndrome. $O \mathcal{Y}$ Med New Ser 1981; 199: 279-95.

8 Quie P G. Neutrophil dysfunction and recurrent infection: In: Gallin J I, Fauci A, eds. Advance in host defence In: Gallin J I, Fauci A, eds. Advance in host

9 Whaley K, Webb J, Mc'Avoy B. Sjögren's syndrome 2. Clinical association and immunological phenomena. $Q \mathcal{f}$ Med 1973; 42: 513-48.

10 Hällgren R, Håkansson L, Venge P. Kinetic studies of phagocytosis. I. The serum independent particle uptake by PMN from patients with rheumatoid arthritis and systemic lupus erythematosus. Arthritis Rheum 1978; 21: 107-13.

11 Staples P J, Gerding D N, Decker J L, et al. Incidence of infections in systemic lupus erythematosus. Arthritis Rheum 1974; 17: 1-10.

12 Howe G B, Fordham J N, Brown K A, Currey H L F. Polymorphonuclear cell function in rheumatoid arthritis and in Felty's syndrome. Ann Rheum Dis 1981; 40: 370-5.

13 Manthorpe R, Oxholm P, Prause J U, Schiödt M. The Copenhagen criteria for Siögren's syndrome. Scand $\mathcal{f}$ Copenhagen criteria for Sjögren's

14 Håkansson $L$, Venge $P$. The influence of serum on random migration and chemotaxis of polymorphonuclear leukocytes: methodological evaluation using sera from infectionprone patients and normals. Scand $\mathcal{F}$ Immunol 1980; 11: 271-82.

15 Håkansson L, Hällgren R, Venge P. Regulation of granulocyte function by hyaluronic acid. In vitro and in vivo effects on phagocytosis, locomotion and metabolism. 7 Clin Invest 1980; 66: 298-305.

16 Wilkinson P. Chemotaxis and inflammation. London: Churchill Livingstone, 1984.

17 Venge P, Artursson G. Locomotion of neutrophil granulocytes from patients with thermal injury. Identification of serumderived inhibitor. Burms 1981; 8: 6-9.

18 Håkansson L, Venge P. Partial characterization and identification of chemokinetic factors in serum. Scand $\mathcal{Y}$ I mmunol fication of chemo

19 Håkansson $L$, Venge $P$. The chemotactic activity of normal and complement activated serum as measured by the leading-front method using Boyden chamber. Scand $\mathcal{J}$ Immunol 1984; 19: 63-73.

20 Siegbahn A, Venge P, Nilsson K, Simonsson B. Identification of a chemokinetic inhibitor in serum from patients with chronic lymphocytic leukaemia. Scand 7 Haematol 1982, 28: 122-31.

21 Hällgren R, Jansson L, Venge P. Kinetic studies of phagocytosis of IgG coated latex particles using a thrombocytosis counter. F Lab Clin Med 1977; 90: 786-95.

22 Trulson A, Nilsson S, Venge P. Lucigenin-enhanced chemiluminescence in blood is increased in cancer. Am Clin Pathol 1989; 91: 65-9.

23 Olofsson T, Olsson I, Venge P. Myeloperoxidase and lactoferrin in blood neutrophils and plasma in chronic lactoferrin in blood neutrophils and plasma in chronic granulocytic leukemia. Scand f Haematol 1977; 18: 113-20.
Pauksens K, Sjölin J, Venge P. Chemiluminescence of polymorphonuclear leukocytes and whole-blood during acute bacterial infections. Scand $\mathcal{F}$ Infect Dis 1989; 21 : 277-84.

25 Bass D A, Olbrantz P, Szejda P, Seeds M C, McCall C E. Subpopulations of neutrophils with increased oxidative production formation in blood of patients with infection. I Immunol 1986; 136: 860-6.

26 Henson P M. Membrane receptors on neutrophils. Immunology Communications 1976; 5: 757-74. 
27 Pennec Y L, Gentric A H, Jouquan J R, Youinou P. Polymorphonuclear cell function in patients with Siögren's syndrome. Clin Exp Rheumatol 1988; 6: 293-6.

28 Schopf R E, Rehder M, Laux B, Korting G W. Functiona Fc-receptor defect of polymorphonuclear leukocytes in a patient with Sjögren's syndrome. Klin Wochenschr 1987; 65: patient

29 Bondestam M, Håkansson L, Foucard T, Venge P. Defects in polymorphonuclear neutrophil function and proneness 685-94.

30 Ambruso D R, Johnston Jr R B. Defects of phagocyte function. In: Chandra R K, ed. Primary and secondary immunodeficiency disorders. Edinburgh, London, Melbourne, New York: Churchill Livingstone, 1979: 133-48.

31 Gallin J I. The cell biology of leukocyte chemotaxis. In: Glynn L E, Houck I C, Weissman G, eds. Handbook of inflammation. Vol 2. The cell biolooy of inflammation. Amsterdam: Elsevier/North-Holland Biochemical Press, 1980: 299-335.

32 Schmekel B, Hakkansson $L$, Häloren R, Stålenheim G, Venge P. Serum mediated inhibition and stimulation of neutrophil locomotion in sarcoidosis. European foumal of Respiratory Disease 1984; 65: 592-9.

33 Horwitz M A. Phagocytosis of microorganisms. Rev Infect Dis 1982; 4: 104-23.

34 Klebanoff S J, Clark R A. The neutrophil function and clinical disorders. Amsterdam: North Holland, 1978.

35 Weiss J, Elsbach P, Olsson I, Odeberg H. Purification and characterization of a potent bactericidal and membrane active protein from the en wacter of human polymorphoactive protein from the granules of human polymorpho

36 Gallin J I. Neutrophil specific granule deficiency. Annual Review of Medicine 1985; 36: 263-74.

37 Review of Medicine 1985; 36: 263-74. Babior B M. The origin of the chemiluminescence of
B phagocytosing granulocytes. 7 Clin Invest 1976; 58: 789-96. 38 Wolach B, Baehner R L, Boxer L A. Clinical and laboratory approach to the management of neutrophil dysfunction. Is Ұ Med Sci 1982; 18: 897-916.

39 MacGregor R R, Spanuolo P J, Leutnek A L. Inhibition of granulocyte adherence by ethanol, prednisolone and aspirin, measured with a new assay system. N Engl f Med 1974; 291: 692-6. 